\title{
Open season for snipes at the media pack
}

For 365 days a year, the media cop it from our pollies. But the overseas press are employed to report on the country and its goings-on - not the whims of our politicians, who, whenever they make a boo-boo, claim they are misreported.

\section{By JAMES PINDER}

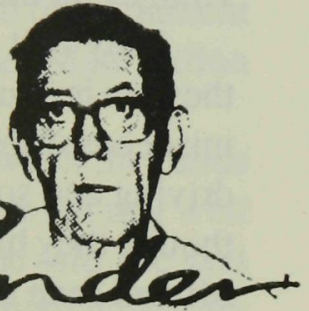

IN MOST countries throughout this world, there are closed seasons for the shooting at, maiming and killing and so on of certain birds and animals. For example, in Australia the wild duck season lasts only two months; in England it is illegal to go pheasant hunting outside of season; in Africa there is a special period in which certain wild animals may be killed or captured - and then purely for culling purposes. But here in Papua New Guinea, as far as our parliamentarians are concerned, there are 365 days a year for them to snipe at the media and what an utter pack of lying, dishonest, yellow-livered, gutless, misreporting fabricators of falsehoods we all seemingly are.

In Parliament in mid-September, the pollies guns opened up again on the media with Moresby North-West MP Albert Karo giving journalists a gobful for reporting an 'incident' at the Airways Motel during the independence celebrations. But firstly let me put to rest the rumour that the World Kick Boxing Association has named Albert as the number-one contender for the next world title championship bout. That rumour was not started by the media even if the television replay shows that if the kick had landed squarely, Hiri Moale Festival organiser Adira Gumasa could legitimately apply for the position of lead soprano in the Vienna Boys Choir for the remainder of his life.

Mr Karo was apologising in Parliament for causing a brawl in front of overseas dignitaries. TV footage showed Mr Karo executing a kick to the midsection of Mr Gumasa's body with his right leg. This was followed by a brawl involving bystanders 'much to the embarrassment of organisers,' according to the Post-Courier. As I wasn't present, I would not know about the bystanders, 


\section{JAMES PINDER}

but the whole of Papua New Guinea is still shocked and disgusted. During his apology, Mr Karo accused the media of 'victimising' him and called for an apology from them for reporting the incident. What utter gall of the man - he must have the hide of a rhinoceros to demand such a childish request. No viewers saw any of the media or the TV cameraman getting involved. You did the deed, Albert, nobody else - so why should it not be reported?

After all, you never bitched when the media covered your presentations of boats and motors and other goodies out of your slush fund to various Papuan villages. Is that victimisation?

Why is it that politicians feel that because they are parliamentarians that they are immune to criticism? If it is good enough for the media to report on the misdeeds of ordinary citizens involved in misappropriation of funds, drunken driving and so on, why should our neglected leaders be classified as sinless as though they had been ordained by God to be angels on a pedestal, ready to take off and save us all from eternal damnation.

Even the Bible reports the good and the bad of the leaders in those days it tells us of paradise and how Adam and Eve buggered that up, Cain knocking off Abel, Pharaoh and his mob being destroyed, various adulterous affairs and so on of the bosses of the times. Need we go on? If it is good enough for the Good Book reporters to write about the misdeeds of the leaders, why can't modern day journalists have their say?

If it is any consolation to Mr Karo and his colleagues, the older generation of journalists and commentators - especially myself - has a little home-spun philosophy, and same is shared by the general public. For the majority, being an MP is a vast subsidised ego trip. It's a job that needs no qualifications, that has no compulsory hours of work, no performance standard, and provides a warm room, a telephone and subsidised meals to a bunch of self-important windbags and busybodies who suddenly find people taking them seriously because they've placed the word 'honourable' before and 'MP' after their names. How can they be underpaid where there's about 200 applicants for every vacancy? You could fill every seat 20 times over even if they had to pay to do the job.

Then the Prime Minister, Big Julie, got into the act and once again the media, especially those from overseas, copped it. JC said the media should be held responsible for what they printed about the crime situation, emphasising that the overseas media were the worst offenders. He called for more investigative journalism into the crime situation because 'you will find other countries beat us hands down.'

Actually, Julius, nobody in the country gives a tinker's cuss about the crime rate in other countries. People are only interested in what happens in their daily lives in their own country - not in New York, Swaziland, Uganda or Bosnia. 
It is politically correct to report on starvation in Ethiopia, the carnage in Rwanda, AIDS in India, massacres in Bosnia, bombings in France and so on. However, it is naughty to write about rapes, child molesting, murders, illiteracy, lack of health facilities and drugs, the failure of the disciplined forces because of no funding by the Government to those three services, the high rate of inflation, and super high prices. All this in our country.

The overseas press are employed here to report on the country and its goings-on - not the whims of our politicians, who, whenever they make a booboo, claim they were misreported. After all, there are a couple still in Parliament who the courts have proven could outshoot Wyatt Earp and Matt Dillon combined in a duel in any Moresby hotel.

The crush - the real blow of the sledge-hammer - came when Sir Julius said he has had to explain to the foreign media that MPs here were not that well looked after. 'Even I find it very difficult to live with my pay,' he said. He said leaders were obliged to pay for the community costs, leaving them with little money.

There are words and phrases to describe such an inane comment but the laws of censorship prevent me from using them. If Julius can't live on K200,000 a year, and vice-ministers on a miserable K82,335 a year, what chance do our labourers have on K2500 a year? Of course, the labourers and the settlement residents don't go to five-star hotels - they're lucky these days to be able to buy bread, let alone cake.

$\square$ James Pinder, the alter ego of Paul Cox, is a columnist on the Saturday Independent. This article, under the headline 'The continuous season of media bashing', was published in the 30 September 1995 edition. 